\title{
Meaningful and contextualised grammar instruction: What can foreign language textbooks offer?
}

\section{Introduction}

Grammar instruction in current foreign language (FL) teaching requires a different approach than the traditional, well-known practice- and production-based models dominated by mechanical drills and detached sentences. FL teaching around Europe today is guided by the Common European framework of reference for languages (CEFR) (Council of Europe 2001), which recommends an action-oriented approach that emphasizes interaction and real-world applications. In order to align with such principles, grammar instruction needs to be contextualised and provide students with the ability to connect form and meaning. While the literature presents a range of methodological options for grammar exercises upon which teachers can draw in their practice (see, e.g., Ellis 2002; Van Patten 1996), little is known about the extent to which these various options are actually used by teachers in FL classrooms. Previous research from many different countries has shown that FL teachers often rely heavily on textbooks in their teaching (see Brown 2014 for a list of references from different countries), and it is therefore reasonable to assume that the variation in grammar exercises in textbooks reflects to some extent the variation in grammar exercises offered to students in FL classrooms. In many countries, a tendency to rely heavily on textbooks co-occurs with goaloriented curricula that specify neither content nor methodology. The teachers themselves are thus in charge of content-related and methodological decisions and will often turn to a textbook for guidance. Norway is one country with such a goal-oriented curriculum (Norwegian Directorate of Education and Training 2006), and where reports have shown that many FL teachers rely heavily on course books (Speitz and Lindemann 2002). Findings from the Norwegian context, in which this study is set, should therefore be of relevance to other countries with similar FL teaching contexts.

Textbooks are only one of several resources available for FL teachers. However, given the fact that they play such an important role in the FL classroom, it is essential that they are of high quality, offer varied teaching materials and are up to date on recent developments within the research fields of second language acquisition (SLA) and language pedagogy. Nevertheless, previous research on textbooks for different languages and from different contexts has shown that this is not always the case; many textbooks' methodological options 
for grammar exercises are limited (see, e.g., Aski 2003; Ellis 2002; Fernandéz 2011; Haukås, Malmqvist and Valfridsson 2016). To my knowledge, no studies thus far have investigated grammar exercises in French FL textbooks available in Scandinavia. Since FL teachers in Scandinavia are expected to teach grammar according to principles from communicative language teaching (CLT) and the more recent action-oriented approach, while taking charge of content and methodology themselves, it is important to determine the extent to which textbooks can support them in this work. This article therefore aims to examine the extent to which current French FL textbooks can help teachers provide students with meaningful and varied grammar exercises. The objective is to gain insights about the potential need for supplementary material or enhanced focus on varied methods of teaching grammar in pre- or in-service teacher education as well as insights that can be useful for textbook authors. In addition, the methodology outlined in this article offers a typology of grammar exercises and a set of analytical procedures that can be adopted in other contexts, thus allowing for comparisons across languages and textbook markets.

\section{Theoretical background and literature review}

\section{The changing role of grammar instruction in FL learning}

The role of grammar teaching in FL learning has been a subject of much debate within the research fields of SLA and language pedagogy. One issue that has been extensively discussed since it was first raised by Krashen's input hypothesis in the 1970s and 1980s (Krashen 1977, 1985 ) is whether it is useful at all to employ explicit grammar teaching or whether teachers instead should allow students to implicitly acquire grammar skills through exposure to extensive input. Nowadays, scholars seem to agree that for FL learning in school settings, explicit grammar teaching is necessary because there is not enough time or input for students to implicitly acquire the structure of the target language.

While grammar instruction was downgraded during the early phase of the CLT paradigm, grammar was later reintroduced as an important element, albeit not in the same way as before. Within current FL programs inspired by the later phases of CLT and/or the action-oriented approach described by the Council of Europe (2001), grammar knowledge is not considered a learning objective in itself, but a useful tool for the development of communicative skills. In these frameworks, actual language use - not linguistic analysis - is the focus. These paradigms therefore demand a contextual approach to grammar, with grammar learned in 
relation to meaning-making and communicative situations. In current grammar instruction, it is therefore essential to establish links between form, meaning and use (Ellis 2002, 2006; Van Patten 1996, 2002; DeKeyser 1998; Calvé 1994; Larsen-Freeman 1995).

The communicative turn in language teaching, together with an increased focus on learnercentredness and authentic material, eventually laid the foundation for other, more meaningfocused methods of teaching grammar. Van Patten (1996), for instance, proposed a model of input processing instruction (PI) and overall, SLA literature tended to recommend more inputoriented and induction-based approaches to grammar instruction.

\section{Which methods "work best"?}

Today, a range of methodological options for grammar exercises are available, from traditional production-based exercises that aim to automatise linguistic structures to inputbased tasks that demand analytical skills and an understanding of the meaning of linguistic forms (Ellis 2002). Although most researchers agree that explicit grammar instruction is necessary, there is no consensus regarding how this explicit grammar teaching should be carried out in order to maximise its effectiveness. Van Patten and Uludag (2011), for example, cite a number of studies that show the effectiveness of the PI model (e.g. Benati and Lee 2008) and demonstrate in their own study how PI not only leads to enhanced metalinguistic knowledge, but also to improved production skills. However, a number of studies have compared various methods and found no difference in effectiveness. For example, in an experimental study set up by Jean (2005), two groups of French L2 learners in Canada received two different types of instruction on the conditional. One group received traditional grammar instruction with a large number of mechanical drills that allowed the learners to practice forming conditionals, while the other group received more input-oriented and meaning-focused tasks that the learners could not solve without fully understanding the content of the texts with which they worked and the forms to be used. The outcome of the instruction was determined by a series of measures, such as fill-in-the-blank exercises and communicative tasks linked to free oral and written production. The groups made equal progress according to all measures. A study by Tammenga-Helmantel et al. (2014) shows similar results. Dutch students learning English, Spanish or German as L2 were divided into groups that received four different types of instruction (deductive, inductive, implicit and incidental) about the same grammatical phenomenon, while one control group did not receive any instruction about this phenomenon. The groups' progress was measured by pre-tests and 
post-tests focused on the learners' metalinguistic knowledge and production of the grammatical structure in question. The authors concluded that 'no strong claims about the most effective instruction form could be made' (Tammenga-Helmantel et al. 2014, 209).

The lack of conclusive findings is hardly surprising. Obvious reasons for this include different research designs and different measures of skills and competencies. Moreover, individual students have different learning styles, different student groups are used to different teaching methods and teachers have different preferences and levels of familiarity with different methods. Therefore, there is no 'one size fits all' method for individuals or student groups, and it is not always useful to investigate which method works 'best'. In line with Ur (2011) and Batstone and Ellis (2009), I argue that it is more important to ensure that FL teachers have easy access to a range of methodological options and know how to use them.

\section{Methodological options in teaching material}

Despite the existence of a range of methodological options for teaching grammar, the extent to which these options are actually used by FL teachers in the classroom remains unclear. It is clear from previous research that the shift towards more input-oriented and induction-based exercises is not necessarily reflected in actual practice or teaching materials (see Jean 2005, 520-521). Ellis (2002) studied the typology of grammar exercises in six popular textbooks teaching English and found that traditional controlled production-based exercises were most common. Only two books provided a limited number of opportunities for students to discover for themselves how an aspect of grammar works. Ellis $(2002,160)$ concluded that the grammar practice books he studied were not very different from those published in previous decades.

At about the same time, Aski (2003) undertook a similar investigation into introductory Italian textbooks. She also found that communicative practice activities were rare. The books relied heavily on mechanical drills as well as on a task type Aski called "communicative drills" and which she described as highly formulaic and structured with an easily recognizable pattern, but where meaning has to be processed and understood (see the Methods section). Interestingly, input-based activities were not included in Aski's analysis because they did not exist in the books (Aski 2003, 64). 
About a decade later, in a period of eclecticism, one might expect to find increased diversity in grammar exercises. However, a study by Fernandéz (2011) and a recent study by Haukås, Malmqvist and Valfridsson (2016) suggest otherwise. Fernandéz (2011) applied Ellis' typology to introductory Spanish textbooks and reached a conclusion similar to Ellis': there was a strong tendency towards controlled production activities. Nevertheless, she identified some signs of change; some textbooks included more input-based activities and communicative tasks (Fernandéz 2011, 164-165). Haukås, Malmqvist and Valfridsson (2016) analysed the various types of grammar exercises offered in German FL textbooks sold in Norway and Sweden, respectively, concluding that the available options were limited primarily to traditional output-oriented exercises. Maijala and Tammenga-Helmantel (2017) also studied German FL textbooks, focusing on books optimised for the Finnish and the Dutch market, respectively. They found that traditional fill-in-the-blanks exercises constituted the most frequent exercise type. Discovery-based exercises were also present in many of the books, but these often had obvious answers and were not challenging. Exercises that encourage reflective or contrastive approaches were rare. Maijala and Tammenga-Helmantel $(2017,16)$ call for more research on FL textbooks for other languages and from different countries in order to confirm whether the tendencies they found hold universally true.

Of the above-mentioned studies, only Haukås, Malmqvist and Valfridsson's targets textbooks optimised for the Scandinavian market. Moreover, unlike German FL textbooks, there are to my knowledge no recent studies on grammar in French FL textbooks. Some studies of grammar approaches in French FL textbooks were conducted in the 1990s, and they showed, unsurprisingly, that textbooks relied on traditional methods of presenting grammar and featured an abundance of mechanical drills (Shelly 1995; Mitchell, Tucker and Redmonds 1993; both cited in Aski 2003). However, in the late 1990s, Lally (1998, cited in Aski 2003) identified some progress in the way grammar was treated in introductory French textbooks.

In order to contribute to the research field with updated findings, this article aims to examine approaches to grammar instruction in current French FL textbooks designed for use in Norwegian schools. I use a framework for analysis that builds on Ellis' (2002) typology of methodological options and the classification system outlined in Aski (2003), which places activities on a continuum depending on the extent to which they establish links between form and meaning.

The present study has been guided by the following research questions: 
To what extent do grammar exercises offered in French FL textbooks reflect different methodological approaches?

To what extent do the grammar exercises combine focus on form with focus on meaning and use?

\section{Materials and methods}

\section{Materials}

I studied the grammar exercises offered in a selection of French FL textbooks produced for the Norwegian market; two textbooks for lower secondary school, C'est chouette (Gyldendal Publishing House) and Ouverture (Fagbokforlaget), and two for upper secondary school, Enchanté (Cappelen Publishing House) and Contours (Gyldendal Publishing House). They were selected because they are among the most widely used French textbooks in Norwegian schools and because they are produced to meet the demands of the Norwegian curriculum for FLs, which in turn builds on the CEFR. The lower secondary books teach French at the beginner level, and the upper secondary books teach at an intermediate level. In lower secondary school, students use a series of three books over three years. This study focuses on the first book, through which learners are first introduced to the French language. The indepth analysis of the grammar exercises covers the first half of the material designed to be used in the first year (chapters 1-6 of 12 for both books). Similarly, at the upper secondary level, this study focuses on the material in the first intermediate-level book, and the in-depth analysis covers the first half (or slightly more) of this material. The most recent editions of all four books were chosen. Supplementary materials such as CDs, websites and teachers' guides were not examined in this study. Table 1 provides an overview of the relevant textbook material used at the beginner and intermediate levels in Norwegian schools and identifies which part of this material was studied. 
Table 1: Overview of textbook material used in schools and the parts analysed in this study.

\begin{tabular}{|c|c|c|c|}
\hline Level & Grade/year & Textbook used & $\begin{array}{l}\text { Object of } \\
\text { investigation }\end{array}$ \\
\hline \multirow{6}{*}{ Beginner level } & \multirow[t]{2}{*}{$\begin{array}{l}\text { Lower secondary } \\
\text { Year } 1\end{array}$} & $\begin{array}{l}\text { C'est chouette } 1 \text { (2006) } \\
\text { Lessons 1-12 }\end{array}$ & $\begin{array}{l}\text { C'est chouette } \\
1 \text { Lessons 1-6 }\end{array}$ \\
\hline & & $\begin{array}{l}\text { Ouverture } 1 \text { (2006) } \\
\text { Lessons 1-12 }\end{array}$ & $\begin{array}{l}\text { Ouverture } 1 \\
\text { Lessons 1-6 }\end{array}$ \\
\hline & \multirow[t]{2}{*}{$\begin{array}{l}\text { Lower secondary } \\
\text { Year } 2\end{array}$} & $\begin{array}{l}\text { C'est chouette } 2 \text { (2007) } \\
\text { Lessons 1-12 }\end{array}$ & \\
\hline & & $\begin{array}{l}\text { Ouverture } 2 \text { (2007) } \\
\text { Lessons 1-12 }\end{array}$ & \\
\hline & \multirow[t]{2}{*}{$\begin{array}{l}\text { Lower secondary } \\
\text { Year } 3\end{array}$} & $\begin{array}{l}\text { C'est chouette } 3 \text { (2008) } \\
\text { Lessons 1-12 }\end{array}$ & \\
\hline & & $\begin{array}{l}\text { Ouverture } 3 \text { (2008) } \\
\text { Lessons 1-12 }\end{array}$ & \\
\hline \multirow{4}{*}{$\begin{array}{l}\text { Intermediate } \\
\text { level }\end{array}$} & \multirow[t]{2}{*}{$\begin{array}{l}\text { Upper secondary } \\
\text { Year } 1\end{array}$} & $\begin{array}{l}\text { Contours nouvelle édition } 1+2 \\
\text { Lessons } 1-5\end{array}$ & $\begin{array}{l}\text { Contours 1+2 } \\
\text { Lessons 1-3 } \\
\end{array}$ \\
\hline & & $\begin{array}{l}\text { Enchanté } 1 \text { (2012) } \\
\text { Lessons 1-12 }\end{array}$ & $\begin{array}{l}\text { Enchanté } 1 \\
\text { Lessons 1-6 }\end{array}$ \\
\hline & \multirow[t]{2}{*}{$\begin{array}{l}\text { Upper secondary } \\
\text { Year } 2\end{array}$} & $\begin{array}{l}\text { Contours nouvelle édition } 1+2 \\
\text { Lessons } 6-10\end{array}$ & \\
\hline & & $\begin{array}{l}\text { Enchanté } \\
2 \text { (2013) } \\
\text { Lessons 1-12 }\end{array}$ & \\
\hline
\end{tabular}

\section{Procedure and analytical framework}

I first read through all the chapters of each book to verify that they used similar approaches to teach grammar. This ensured that analysing only the first part of each book would not bias the results. No chapters stood out in terms of the methodological options for grammar exercises. 
Identification of relevant exercises

I used a two-step procedure to identify the grammar exercises in the selected chapters. First, all the books marked the grammar exercises in some way (usually with a colour code, often combined with a letter specific to each section), and so I retained these exercises for analysis. However, limiting the analysis to explicitly marked grammar exercises is not enough. With such a selection, the researcher either consciously omits data or assumes that textbook writers treat grammar as something learnt separately from 'the rest' of a language. However, grammar should be taught as an integrated part of the language, hence it is reasonable to assume that grammar training is at least somewhat integrated into the training of communicative skills. A more holistic approach is therefore needed, and the second step consisted of a thorough reading of all the exercises in the chapters. In three of the four books, I found exercises that clearly taught grammar but were not specifically marked as grammar exercises. In order to distinguish exercises that clearly taught grammar (without being marked as such) from other types of exercises, I retained for analysis those exercises that explicitly mentioned a grammar point and/or were directly connected with an explanation of the grammar point that the proposed activity targeted. For instance, in one of the books, a frame titled 'Structures' that contained examples of interrogative structures was immediately followed by an exercise in which the students were to ask each other various questions about their families (Ouverture, p. 63). This was classified as a grammar exercise targeting interrogative structures. A similar task without such an introductory frame would not qualify as a grammar task unless it was explicitly stated that the students should use interrogative structures. This means that some open exercises with the potential to teach grammar are not classified as grammar exercises because they are open rather than controlled. However, when textbook authors do not explicitly state the connection between grammar and free use of language, the teacher is responsible for using the exercise to teach grammar. In other words, in these cases, textbooks do not support the teacher in terms of grammar instruction, which justifies the exclusion of these exercises from the analysis.

This holistic approach differs from what has been common in previous research, which tended to focus specifically on grammar books or grammar sections in regular textbooks. With the approach adopted in the present study, also grammar training which is mixed in with the practice of communicative skills are captured by the analysis, as long as the grammar focus is made explicit by the textbook authors. 
Typology of exercises

I use a typology of grammar exercises that is heavily influenced by the typology developed by Ellis (2002). In the following, I summarise Ellis' typology and specify some minor adjustments I made.

Ellis' typology is based on three sets of options concerning explicit description, data and operations. As Ellis $(2002,159)$ explains, explicit description refers to whether the explanatory text of the exercise provides the learner with an explicit explanation of the grammar point (i.e. a deductive approach; Ellis terms this category 'supplied') or whether it requires learners to develop their own explanation (i.e. an inductive approach, termed 'discovery' in Ellis' typology). In the present study, this category is re-labelled surrounding text because I find it a more neutral expression than the original; if the text encourages the learners to discover explanations on their own, it can hardly be called explicit. Sometimes there is no descriptive text associated with the exercise, only instruction (e.g. 'Fill in the correct form of the verb'). In these cases, the columns for this set of options will be empty (see Table 2), unless the instruction includes finding a grammatical rule, in which case the exercise would be marked as inductive. Also, if the instruction refers to another section in the book with information about the phenomenon in question (usually an explicit explanation; e.g. 'See the grammar section, p. x, on verb conjugation. Fill in the correct from of the verb'), the exercise will be marked accordingly.

The data category (renamed sample of language in Fernandéz 2011) refers to the nature of the material used to illustrate the target structure. As Ellis (2002) explains, this category has three subcategories: source, which refers to whether the provided text is authentic or contrived; size, which concerns whether the data consists of discrete sentences or continuous text; and medium, which refers to whether the data consist of written or oral material. For the subcategory medium, I added a third option: visual material. Purely illustrative pictures are not counted; I only count visual material designed to be actively used by students to perform the task. There is also a fourth option: no data. For example, in an exercise in which students are asked to tell each other what they did yesterday while using the French verb tense passé composé, there is no data illustrating the target structure. Unlike Ellis (2002, 159), I did not restrict the data category to sample language that occurred independently of the text associated with the operations, instead analysing all sample language as data, including gapped sentences or texts. 
Finally, the operations category concerns the type of activity students are required to perform. In my framework, I label this category student activity. Again, there are three subcategories in Ellis' typology: production, which means that students have to produce output containing the target structure; reception, which means that students are required to demonstrate that they understand sentences containing the target structure; and judgment, which means that students are required to identify whether sentences containing the target structure are grammatically correct. Since the latter two categories (reception and judgment) are both input-based activities (they both require that the students process and reflect upon linguistic input containing the target structure), I have, in line with Fernandéz (2011, 162), chosen to subsume them under a common category, input-based activities. My student activity category thus consists of two distinct and opposing subcategories: production-based activities and inputbased activities. Both can be further sub-divided: Production-based activities, for example, can be controlled (students are provided with text that they must interact with in a way that involves the target structure) or free (students are required to create their own sentences). This distinction is a continuum rather than a dichotomy (Ellis 2002). Furthermore, there are many different subtypes of controlled production-based activities depending on the type of activity students are asked to perform. The most common types are gap-filling (completion), substitution and transformation activities. Translations into French are also considered controlled production-based activities. Input-based activities can be further subdivided into activities such as input categorisation (students must sort input according to certain criteria), formulation of rules or hypotheses (which are often related to the 'inductive' category in the first set of options), language comparison and, as mentioned above, judgment tasks. Translation activities from French into Norwegian were also considered to be input-based.

Figure 1 provides an overview of this typology.

\section{$<$ Figure 1 here>}

In order to answer the second research question, production-oriented activities were further analysed according to Aski's (2003) typology. Four categories are defined and situated on a continuum from weak to heavy focus on meaning and use. Mechanical drills are the least meaning- and use-focused; in mechanical drills, the learner need not understand the meaning of the sample language, and there is only one correct answer. Typical examples are completion, transformation and substitution activities. The next two categories, Meaningful and Communicative drills are often hard to distinguish and will be subsumed under one 
category in this study. They are highly formulaic and structured exercises with an easily recognisable pattern, but the learners must understand the content in order to solve the task successfully. Whereas meaningful drills have only one correct answer, there are no right or wrong answers in communicative drills. Examples of meaningful drills are completion activities in which students must select the right tense, verb or mode, question-and-answer sequences based on given information that is accessible to everyone, translations into French, and activities in which students have to correctly combine jumbled words. Examples of Communicative drills include e.g. interviews with pre-defined questions but variable answers (e.g. 'yes' and 'no'). Communicative language practice activities are genuinely communicative (i.e. they are purposeful activities that involve new, unknown information and are set in real or simulated communicative settings). The criterion related to setting is important; for instance, a writing activity in Ouverture asking the student to 'write down two types of sport that you like' (p. 46) does not meet the criteria for communicative language practice because it does not specify to whom the student should address this short text and the context in which it could be used. Examples of genuinely communicative activities could be role-playing activities, interviews without a strict pattern, classroom discussions and playful individual or collaborative task-based activities.

Two questions guided classification of the exercises: 1) Do the students have to understand the content of the sample language in the exercises? and 2) Are the exercises situated in a communicative setting? A negative answer to both questions means the activity should be considered a mechanical drill. A positive answer to the first question and a negative answer to the second categorises the activity as a meaningful drill, while a positive answer to both questions means the activity should be placed in the communicative language practice category.

\section{Findings}

Tables 2, 3 and 4 present the findings related to the three sets of options. Table 5 presents the quantitative findings of further analysis of the production-based activities.

For Table 4, it must be noted that the same exercise might include several types of student activities. For instance, exercises in Contours often ask the students to fill in the blank (e.g. with the correct form of a verb) and then translate into Norwegian. In line with Aski (2003), I counted the number of activities rather than the number of exercises, and the percentages 
listed in Table 4 are calculated based on the number of activities. Ouverture thus has 34 exercises, but 50 activities.

In Tables 2 and 3 (surrounding text and source type/size/medium), on the other hand, each exercise (not each activity) is analysed because all activities in one exercise usually originate from the same material. When an exercise has several parts (a, b, c, etc.), each part is counted as an individual exercise if it is clearly distinguished from the others (e.g. they are based on different materials, involve different types of operations or target different phenomena). When the different parts appear more as a series of questions targeting the same phenomenon and the same type of operation, they are counted as one exercise. Table 5 presents all exercises that include production-oriented activities.

I will first present the findings for each school level and then synthesise the results and comment upon the main findings.

Table 2: Role of surrounding text

\begin{tabular}{|l|c|c|c|c|c|c|c|c|}
\hline & \multicolumn{2}{|c|}{ Chouette } & \multicolumn{2}{c|}{ Ouverture } & \multicolumn{2}{c|}{ Contours } & \multicolumn{2}{c|}{ Enchanté } \\
\hline & & & & & & \\
\hline Surrounding text & $\%$ & $\mathbf{N}$ & $\mathbf{\%}$ & $\mathbf{N}$ & $\mathbf{\%}$ & $\mathbf{N}$ & $\mathbf{\%}$ & $\mathbf{N}$ \\
\hline Deductive/explanatory & $4 \%$ & 2 & $18 \%$ & 6 & $47 \%$ & 36 & $58 \%$ & 60 \\
\hline Inductive/suggestive & $15 \%$ & 7 & $24 \%$ & 8 & $2 \%$ & 1 & $4 \%$ & 4 \\
\hline Both & - & - & $21 \%$ & 7 & - & - & $2 \%$ & 2 \\
\hline None & $81 \%$ & 38 & $38 \%$ & 13 & $52 \%$ & 40 & $36 \%$ & 37 \\
\hline Total & $\mathbf{1 0 0} \%$ & $\mathbf{4 7}$ & $\mathbf{1 0 0} \%$ & $\mathbf{3 4}$ & $\mathbf{1 0 0 \%}$ & $\mathbf{7 7}$ & $\mathbf{1 0 0 \%}$ & $\mathbf{1 0 3}$ \\
\hline
\end{tabular}


Table 3: Overview of the nature of sample language in terms of source type, size and medium. Percentages are calculated based on the number of exercises that include the sample language.

\begin{tabular}{|c|c|c|c|c|c|c|c|c|}
\hline & \multicolumn{2}{|c|}{ Chouette (47) } & \multicolumn{2}{|c|}{ Ouverture (34) } & \multicolumn{2}{|c|}{ Contours (77) } & \multicolumn{2}{|c|}{ Enchanté (103) } \\
\hline Source & $\%$ & $\mathbf{N}$ & $\%$ & $\mathbf{N}$ & $\%$ & $\mathbf{N}$ & $\%$ & $\mathbf{N}$ \\
\hline Contrived & $100 \%$ & 47 & $96 \%$ & 25 & $85 \%$ & 61 & $88 \%$ & 84 \\
\hline Authentic & - & - & $4 \%$ & 1 & $15 \%$ & 11 & $12 \%$ & 11 \\
\hline Size of text & $\%$ & $\mathbf{N}$ & $\%$ & $\mathbf{N}$ & $\%$ & $\mathbf{N}$ & $\%$ & $\mathbf{N}$ \\
\hline Discrete sentences & $89 \%$ & 42 & $77 \%$ & 20 & $65 \%$ & 47 & $67 \%$ & 64 \\
\hline Continuous text & $4 \%$ & 2 & $15 \%$ & 4 & $31 \%$ & 22 & $23 \%$ & 22 \\
\hline Both & $2 \%$ & 1 & - & - & - & - & & \\
\hline Medium & $\%$ & $\mathbf{N}$ & $\%$ & $\mathbf{N}$ & $\%$ & $\mathbf{N}$ & $\%$ & $\mathbf{N}$ \\
\hline Written & $89 \%$ & 42 & $65 \%$ & 17 & $92 \%$ & 66 & $79 \%$ & 75 \\
\hline Oral & $2 \%$ & 1 & $12 \%$ & 3 & $1 \%$ & 1 & - & - \\
\hline Images & $4 \%$ & 2 & $8 \%$ & 2 & $4 \%$ & 3 & $11 \%$ & 10 \\
\hline Combinations & $4 \%$ & 2 & $15 \%$ & 4 & $3 \%$ & 2 & $9 \%$ & $10^{1}$ \\
\hline No sample lang. & & & & 8 & & 5 & & 8 \\
\hline
\end{tabular}

\footnotetext{
${ }^{1}$ All combinations are written and visual.
} 
Table 4: Overview of the types of exercises offered in the textbooks

\begin{tabular}{|c|c|c|c|c|c|c|c|c|}
\hline & \multicolumn{2}{|c|}{ Chouette } & \multicolumn{2}{|c|}{ Ouverture } & \multicolumn{2}{|c|}{ Contours } & \multicolumn{2}{|c|}{ Enchanté } \\
\hline \multicolumn{9}{|l|}{ Production-based act. } \\
\hline Written & $\%$ & $\mathbf{N}$ & $\%$ & $\mathbf{N}$ & $\%$ & $\mathbf{N}$ & $\%$ & $\mathbf{N}$ \\
\hline Completion & $28 \%$ & 17 & $12 \%$ & 6 & $32 \%$ & 31 & $23 \%$ & 30 \\
\hline Substitution & $2 \%$ & 1 & $8 \%$ & 4 & - & - & - & - \\
\hline Transformation & $3 \%$ & 2 & $4 \%$ & 2 & $16 \%$ & 15 & $9 \%$ & 12 \\
\hline Translation (No-Fr) & $15 \%$ & 9 & $12 \%$ & 6 & $14 \%$ & 13 & $10,5 \%$ & 14 \\
\hline Jumbled words & $3 \%$ & 2 & - & - & $2 \%$ & 2 & $4,5 \%$ & 6 \\
\hline 'Free' written prod. & - & - & $16 \%$ & 8 & $10 \%$ & 10 & $12 \%$ & 16 \\
\hline Total written & $51 \%$ & 31 & $52 \%$ & 26 & $74 \%$ & 71 & $59 \%$ & 78 \\
\hline Oral & $\%$ & $\mathbf{N}$ & $\%$ & $\mathbf{N}$ & $\%$ & $\mathbf{N}$ & $\%$ & $\mathbf{N}$ \\
\hline Controlled oral prod. & $5 \%$ & 3 & $6 \%$ & 3 & $5 \%$ & 5 & $16 \%$ & 21 \\
\hline ‘Free' oral prod. & $3 \%$ & 2 & $2 \%$ & 1 & $2 \%$ & 2 & $12 \%$ & 16 \\
\hline Total oral & $8 \%$ & 5 & $8 \%$ & 4 & $7 \%$ & 7 & $28 \%$ & 37 \\
\hline Total production-based & $59 \%$ & 36 & $60 \%$ & 30 & $81 \%$ & 78 & $87 \%$ & 115 \\
\hline Input-based activities & $\%$ & $\mathbf{N}$ & $\%$ & $\mathbf{N}$ & $\%$ & $\mathbf{N}$ & $\%$ & $\mathbf{N}$ \\
\hline Find rules & $10 \%$ & 6 & $16 \%$ & 8 & $4 \%$ & 4 & $2 \%$ & 3 \\
\hline Compare languages & $5 \%$ & 3 & $12 \%$ & 6 & - & - & - & - \\
\hline Categorise input & $8 \%$ & 5 & $8 \%$ & 4 & $5 \%$ & 5 & $7,5 \%$ & 10 \\
\hline Match structures & $8 \%$ & 5 & $2 \%$ & 1 & $1 \%$ & 1 & $1 \%$ & 1 \\
\hline Translation (Fr-No) & $10 \%$ & 6 & $2 \%$ & 1 & $8 \%$ & 8 & $3 \%$ & 4 \\
\hline Total input-based & $41 \%$ & 25 & $40 \%$ & 20 & $19 \%$ & 18 & $13 \%$ & 18 \\
\hline Total & $100 \%$ & 61 & $100 \%$ & 50 & $100 \%$ & 96 & $100 \%$ & 133 \\
\hline
\end{tabular}

Table 5: Distribution of different types of production-based exercises.

\begin{tabular}{|c|c|c|c|c|c|c|c|c|}
\hline & \multicolumn{2}{|c|}{ Ouverture } & \multicolumn{2}{|c|}{ Chouette } & \multicolumn{2}{|c|}{ Contours } & \multicolumn{2}{|c|}{ Enchanté } \\
\hline $\begin{array}{l}\text { Production-oriented } \\
\text { exercise }\end{array}$ & $\%$ & $\mathbf{N}$ & $\%$ & $\mathbf{N}$ & $\%$ & $\mathbf{N}$ & $\%$ & $\mathbf{N}$ \\
\hline Mechanical drills & $25 \%$ & 6 & $54 \%$ & 19 & $45 \%$ & 32 & $32 \%$ & 32 \\
\hline Meaningful drills & $58 \%$ & 14 & $40 \%$ & 14 & $45 \%$ & 32 & $53 \%$ & 52 \\
\hline $\begin{array}{l}\text { Communicative } \\
\text { language practice }\end{array}$ & $17 \%$ & 4 & $6 \%$ & 2 & $10 \%$ & 7 & $15 \%$ & 15 \\
\hline Total & $100 \%$ & 24 & 100 & 35 & $100 \%$ & 71 & $100 \%$ & 99 \\
\hline
\end{tabular}




\section{Lower secondary textbooks}

The lower secondary textbooks offer a mixture of deductive and inductive exercises.

Ouverture has relatively few grammar exercises, but offers an equal number of deductive and inductive exercises. The exercises in Chouette are rarely accompanied by explanatory or suggestive text - they simply contain a brief instruction about what activity to perform -, and they are therefore rarely labelled as either deductive or inductive (see Table 2). However, when the instruction asks students to formulate rules based on examples, this is considered inductive, as pointed out in the Methods section. Thus, seven exercises are classified as inductive. Regarding material, written, contrived, discrete sentences are clearly the norm in Chouette, whereas Ouverture also offer exercises based on oral material or on combinations of oral, written and visual material. Nevertheless, even in this book the material offered is contrived and exercises are rarely based on continuous texts.

When it comes to student activity, there is much variation in the books for the lower secondary level. In Ouverture, no single category stands out as dominating. The two most frequent activity types are free production-oriented writing exercises and input-based 'formulate rules' exercises. In some instances of this latter type, the answer to the discoverybased question is provided immediately after the question. This significantly reduces the challenge of the task, since the student has full access to the answer by a short glimpse (see also Maijala and Tammenga-Helmantel 2017). These two most frequent activity types are closely followed by completion exercises, translations into French (both of which are production-based) and comparison of languages (input-based), each of which occurs six times. In Chouette, the most frequently used type of student activity is completion, followed by translation into French. This is consistent with the traditional pattern common in previous textbooks. Yet, the proportion of input-based activities is quite high (41\%). Many of these are however limited to 'translate into Norwegian' activities without subsequent questions for reflection - an observation that mirrors Maijala and Tammenga-Helmantel's $(2017,9)$ findings. Such translation tasks do not necessarily ensure deep processing of the input, and their value as input-based activities might be limited. Still, 'formulate rules' activities are equally common.

As specified in the Methods section, exercises which include one or more production activities (35 of the 47 exercises in Chouette and 24 out of 34 in Ouverture) were analysed further to determine the extent to which they create links between form and meaning and 
between form and use. In Chouette, more than half of the exercises fall in the category mechanical drills, while about $40 \%$ are meaningful / communicative drills. The majority of the meaningful/communicative drills are translation activities. Very few of the exercises are classified as communicative language activities (see Table 5). In Ouverture on the other hand, only $25 \%$ of the production-based grammar activities are mechanical drills, while $58 \%$ are categorised as meaningful/communicative drills and $17 \%$ are categorised as communicative language practice. This is a pattern which at least up till now has been very rare, judging from previous research in the field.

The lower secondary books thus seem to have somewhat different profiles. Chouette appears very traditional in terms of the material on which grammar exercises are based, but it tends to include a wider range of student activities than what is traditionally common, although a majority of the activities are mechanical drills. Ouverture includes less traditional options such as exercises based on oral material, a significant portion of inductive activities and a strong emphasis on meaning-based exercises.

\section{Upper secondary textbooks}

Both textbooks for the upper secondary level have a clear deductive profile. This is especially salient in Contours, where all but one of the exercises for which a surrounding text is provided, contains an explanatory (as opposed to a suggestive) text. As for the type of material that the exercises are based on, both textbooks favour contrived, written material. However, some exercises are based on authentic material (15\% in Contours and $12 \%$ in Enchanté) and quite a few are based on continuous text (31\% in Contours and $23 \%$ in Enchanté, see Table 3). One interesting observation is that out of the grammar exercises that are based on authentic material, none in Contours are explicitly labelled by the textbook authors as grammar exercises and in Enchanté only half of them are labelled as such.

When it comes to student activities, both books focus primarily on production-oriented activities. In Contours, the by far most frequent type of student activity is completion, followed by transformation and translation into French (see Table 4). On the other hand, approximately $19 \%$ of activities are input-based, so these types of activities are not absent. However, the most frequent subtype (accounting for nearly half of the input-based activities) is translation into Norwegian. In most cases, this is a secondary activity after a completion task. A typical example is as follows: 'Fill in the blanks with the correct form of aller. Then 
translate the sentences into Norwegian' (Contours, p. 27, my translation). Translations (in both directions) are often a good starting point for comparing languages. However, translations are never used in this way in Contours. In the example mentioned here, there are no follow up-questions asking, for instance, about the different meanings of aller in the different sentences, although the exercise includes example of aller used with meanings as different as 1) a future marker, 2) in the expression Ça va? (How are you?) and 3) with the lexical meaning of $g o$. Thus, the teacher is responsible for ensuring that the input is properly processed and students not only translate the sentences but also actively notice the different meanings that the same verb may have in different contexts. The remaining input-based exercises ask students to formulate rules or hypotheses, to explain linguistic choices or to sort and categorise input in specific ways. Again, it is interesting to note that none of these exercises are explicitly marked as grammar exercises, perhaps because they do not concur with the authors' conception of what a grammar exercise is.

Also in Enchanté written completion is the most frequent type of student activity (23\% of the total number of exercises). Nevertheless, a fair proportion of the production-oriented activities involve oral production (controlled $16 \%$ and free $12 \%$, see Table 4). Unlike Contours, these exercise types are more frequent than translations and transformation activities (which both account for approximately $10 \%$ each). Thus, Enchanté has the largest proportion of oral grammar activities by far but, interestingly, no exercises based on oral source material. Inputbased activities account for $13 \%$ of the exercises. Most of these ask students to categorize and sort input in different ways.

As mentioned above, production-oriented activities were further analysed in terms of their potential for meaning- and usage-based grammar. In Contours, 71 out of 77 exercises include production-based activities and of these, 32 (45\%) are classified as mechanical drills, while another $32(45 \%)$ are classified as meaningful/communicative drills. Only $7(10 \%)$ are communicative language practice activities. Thus, the majority of production-oriented exercises in Contours do not involve real communication. In Enchanté, 99 of the 103 exercises include production-based activities. 32 (32\%) are mechanical drills, whereas 52 $(53 \%)$ are meaningful/communicative drills and $15(15 \%)$ represent communicative language practice. This brings Enchanté closer to the lower secondary textbook Ouverture than to the other upper secondary textbook, Contours, in terms of meaning- and usage-based grammar training activities. 


\section{Synthesis and discussion}

There is a notable difference between the lower and upper secondary textbooks both in terms of methodological approach and choice of material. The upper secondary textbooks clearly favour deductive instruction, but when it comes to material they are more likely than lower secondary books to provide authentic material and continuous texts, although contrived, discrete sentences are the norm also at upper secondary level. Given the students' limited linguistic competence at the lower secondary this level, the use of contrived, brief material is, to some extent, understandable. It is perhaps more surprising that the upper secondary textbooks do not include more authentic and continuous material, especially since the Norwegian curriculum for foreign languages (Norwegian Directorate of Education and Training 2006) clearly favours the use of authentic material at this level.

The rarity of oral material is also notable. This might be explained by the fact that oral and written French differ significantly; many grammatical phenomena are inaudible or difficult to notice in oral discourse. In addition, although course books come with accompanying CDs and digital materials, including sound files, they are primarily tangible, written products.

Although the upper secondary textbooks include more exercises than the lower secondary textbooks, the latter offer a wider range of exercise types. Additionally, even though the lower secondary textbooks clearly have different profiles (Ouverture is much more inductionoriented and offers a wider range of exercises than Chouette), they both include input-based activities and discovery approaches to some extent, while in the upper secondary textbooks, such approaches are rare. For instance, despite the fact that one objective of the national curriculum for FLs is to ensure students' ability to compare linguistic structures across languages (Norwegian Directorate of Education and Training 2006), only the lower secondary textbooks include activities that encourage such comparisons. In many respects, the upper secondary textbooks thus remain quite traditional in their approaches to grammar. However, Enchanté links grammar to oral production more than is traditional.

Thus, there seem to be more traces of the development within the SLA and language pedagogy research fields in the lower secondary textbooks than the upper secondary textbooks. This might be explained by the fact that younger students do not think as analytically as their older peers and therefore need different approaches to grammar. However, although it is clear that there is such a difference between young children and 
adolescents/adults, it is less clear whether such a difference exists between students in year one of lower secondary school (aged 13) and students in year one of upper secondary school (aged 16). Another explanation is that the authors of lower secondary textbooks try harder to motivate students to learn grammar, while the authors of upper secondary textbooks expect more of their audience in terms of motivation and commitment.

There is less of a difference between the lower and upper secondary textbooks regarding the extent to which production-oriented activities are based on meaning and usage than between the textbooks at the same level. Ouverture and Enchanté clearly place more focus on meaning- and usage-based grammar than do their respective competitors, Chouette and Contours. This finding is interesting because it shows that the books are not all the same: Even if they claim to be based on the current curriculum they have different profiles and thus the extent to which they support teachers in grammar instruction will vary. The extent to which grammar is contextualised may be more important than the presence of a wide range of exercise types. As Maijala and Tammenga-Helmantel (2017) pointed out, input-based activities are not necessarily of high quality. Similarly to Maijala and Tammenga-Helmantel's (2017) findings, I found translation into L1 exercises without any reflection activities and I found discovery-based exercises which were not challenging.

Although the lower secondary textbooks are clearly shifting towards more varied approaches to grammar teaching, the general changes in all four books seem to be rather modest given the literature's strong emphasis on the need for change. This finding is to a large extent in line with previous research in the field (Fernandéz 2011; Haukås, Malmqvist and Valfridsson 2016; Maijala and Tammenga-Helmantel 2017), although it seems that some more signs of change were detected in the present study. This difference might be due to a real difference between textbooks for different languages from different contexts, but it might also be due to the holistic approach adopted in the present study, in which all grammar exercises were included and not only those occurring under the heading 'Grammar'. Nevertheless, traditional fill-in-the-blank exercises still dominate in most French as FL textbooks.

There are several possible explanations for the limited amount of change. For instance, some textbook authors may not be aware of the different options that exist and/or the importance of including them. In addition, the limited change might reflect teachers' preferences and market demand. In a study of student teachers' beliefs about grammar instruction, Graus and Coppen (2016) found that the student teachers had a preference for traditional teaching methods, 
although they did become more open towards more meaning-based approaches during the course of their teacher training. Fernandéz (2011) points out that publishing houses make what the majority of teachers want in order to sell the largest amount of books. Thus, do teachers prefer traditional materials, since that is what they know how to use and are used to working with? Previous research has shown that it is challenging to change teachers' practices because they tend to teach how they themselves were taught (Borg 2003). This might mean that many teachers prefer what is familiar and safe out of habit or a lack of time to try new techniques. Interestingly, Ouverture - the most innovative textbook in this study in terms of grammar instruction - is also the least commonly used, while Chouette leads the market for lower secondary French textbooks. There might be other reasons for this than the textbooks' approaches to grammar, but if publishing houses assume that textbooks with innovative approaches to grammar will not sell as well, then they probably will not make them.

I will end this section by addressing some of the limitations of this study. First, this study discussed the range of methodological options offered in grammar exercises, but it did not comprehensively investigate the quality of these exercises. This is especially true for inputbased activities, which were not systematically analysed further in this study, while production-based activities were analysed according to the focus on content and use. Moreover, the study did not investigate the quality of grammar explanations provided in the textbooks. Second, although a textbook analysis can give us a fair idea of what is actually going on in FL classrooms, it does not give us a full picture of how grammar instruction is conducted. Related questions that remain unanswered include the following: How do teachers use the material found in textbooks? What other materials do they use? Fougerose (2001) conducted a survey among teachers of French as a FL in France and found that even if the grammar exercises offered in textbooks were traditional, many teachers created their own material and exercises in order to combine grammar training with meaningful communicative activities. Similarly, in a study of novice FL teachers' challenges, Vold (2017) found that FL teachers generally feel confident about how to teach grammar, which might suggest that they are not dependent on the textbook when teaching grammar. Thus, grammar instruction involves more than what is found in textbooks. 


\section{Conclusion and avenues for further research}

This study investigated the extent to which current French FL textbooks can help teachers provide students with meaningful and varied grammar exercises. An analysis of the grammar exercises offered in textbooks for lower and upper secondary students showed that the lower secondary textbooks included a wider range of different exercise types than did the upper secondary textbooks. The latter textbooks were rather traditional in their approach to grammar, with few input-based exercises and discovery approaches to grammar. However, the upper secondary textbooks more often based grammar tasks on authentic material and continuous text. The textbooks also differed in terms of the focus they placed on meaning and use in connection with grammar.

In brief, the analysis revealed indications that the developments within the SLA field concerning meaningful and contextualised grammar instruction are finally beginning to find their way into teaching material. However, exercises based on less traditional approaches (authentic material, input-based activities) were not always labelled grammar exercises by the textbook authors, which demonstrates the importance of taking a holistic approach when analysing approaches to grammar in textbooks and not limit the analysis to grammar exercises explicitly predefined as such. Despite the modest signs of change, teachers must still, in most cases, add supplementary material in order to fully incorporate the current view of meaningand usage-based grammar instruction into their teaching. This requires them to be aware of the need for such material and the best ways to create it. Thus, in pre- and in-service teacher education, how to teach grammar according to research-based principles should be an area of focus. As mentioned above, grammar instruction involves more than what is found in teaching material. In line with Brown (2014), I argue that, in addition to studies of teaching material, there is a clear need for research that addresses what actually happens in classrooms. Since it is known that teacher questionnaires do not always provide reliable answers, such research should be based on observation data or, preferably, on video data. In line with this need, a number of French-as-a-foreign-language classes have recently been video recorded in an ongoing project at the University of Oslo. This data material opens for a focus on how teachers use grammar teaching material provided in textbooks and which types of supplementary material are used. This will provide a deeper insight into the teacher's role in foreign language grammar instruction. 


\section{References}

Aski, J.M. 2003. "Foreign language textbook activities: Keeping pace with second language acquisition research.” Foreign Language Annals 36: 57-65. doi:10.1111/j.19449720.2003.tb01932.x

Batstone. R., and R. Ellis. 2009. "Principled grammar teaching.” System 37 (2): 194-204. doi:10.1016/j.system.2008.09.006

Benati, A., and J.F. Lee. 2008. Grammar Acquisition and Processing Instruction: Secondary and Cumulative Effects. Bristol: Multilingual Matters.

Borg, S. 2003. “Teacher cognition in grammar teaching: A literature review.” Language Awareness 12 (2), 96-109. doi: 10.1080/09658410308667069

Brown, D. 2014. "The power and authority of materials in the classroom ecology." The Modern Language Journal 98 : 658-661. doi:10.1111/modl.12095

Calvé, P. 1994. «Comment faire de la grammaire sans trahir le discours: Le cas des exercices grammaticaux. » Canadian Modern Language Review / La Revue canadienne des langues vivantes $50: 636-645$.

Council of Europe. 2001. Common European Framework of Reference for Languages: Learning, Teaching, Assessment. Strasbourg: Council of Europe.

DeKeyser, R.M. 1998. "Beyond focus on form: Cognitive perspectives on learning and practicing second language grammar." In Focus on Form in Classroom Second Language Acquisition, edited by C. Doughty and J. Williams, 42-63. Cambridge: CUP.

Ellis, R. 2002. "Methodological options in grammar teaching materials." In New Perspectives on Grammar Teaching in Second Language Classrooms, edited by E. Hinkel and S. Fotos, 155-179. Mahwah, NJ: Lawrence Erlbaum Associates.

Ellis, R. 2006. "Current issues in the teaching of grammar: An SLA perspective.” TESOL Quarterly 40: 83-107. doi:10.2307/40264512. 
Fernández, C. 2011. “Approaches to grammar instruction in teaching materials: A study in current L2 beginning-level Spanish textbooks.” Hispania 94 (1) : 155-170. http://www.jstor.org/stable/23032091.

Fougerouse, M.C. 2001. «L'enseignement de la grammaire en classe de français langue étrangère. » Ela. Études de linguistique appliquée 2 (122) : 165-178.

Graus J., and P.A. Coppen. 2016. "Student teacher beliefs on grammar instruction." Language Teaching Research 20 (5) : 571-599. doi: 10.1177/1362168815603237.

Haukås Å., A : Malmqvist, and I. Valfridsson. 2016. "Sprachbewusstheit und Fremdsprachenlernen. Inwiefern fördert die Grammatik in skandinavischen DaF-Lehrwerken die Sprachbewusstheit der Lernenden?“ Zeitschrift für Interkulturellen Fremdsprachenunterricht 21 (2) : 13-26.

Jean G. 2005. «Intégration de la grammaire dans l'enseignement des langues secondes: Le cas des exercices grammaticaux. » The Canadian Modern Language Review 61 (4): 519-541. doi: 10.3138/cmlr.61.4.519

Krashen S. 1977. "Some issues relating to the monitor model." In Teaching and Learning English as a Second Language: Trends in Research and Practice: On TESOL '77: Selected Papers from the Eleventh Annual Convention of Teachers of English to Speakers of Other Languages, Miami, Florida, April 26 - May 1, 1977, edited by H.D. Brown, C.H. Yorio, and R.H. Crymes, 144-158. Washington, DC: TESOL.

Krashen, S. 1985. The Input Hypothesis: Issues and Implications. London: Longman.

Larsen-Freeman, D. 1995. "On the teaching and learning of grammar: Challenging the myths." In Second Language Acquisition Theory and Pedagogy, edited by F.R. Eckman, D. Highland, P. W. Lee, J. Milcham, and R. R. Weber, 131-150. Mahwah, NJ: Lawrence Erlbaum.

Maijala, M. and M. Tammenga-Helmantel. In print. "Grammar exercises in Dutch, Finnish and global textbooks for teaching German as a foreign language" The Language Learning Journal 0 (0) doi: 10.1080/09571736.2017.1309449. Published online May 16, 2017. 
Norwegian Directorate of Education and Training. 2006. Subject Curriculum for Foreign Languages. Accessed 6 April 2017: http://www.udir.no/k106/FSP1-

$\underline{\text { 01/Hele/Kompetansemaal/foreign-language-level-ii?lplang=eng }}$

Speitz H., and B. Lindemann. 2002. "Jeg valgte tysk fordi hele familien min ville det, men jeg angrer": Status for 2. fremmedspråk i norsk ungdomsskole. ["I chose German because my family wanted me to, but I regret it": Status of the second foreign language in Norwegian lower secondary schools.] Report. Notodden: Telemarksforsking Notodden

Tammenga-Helmantel, M., E. Arends, and E. Canrinus. 2014. "The effectiveness of deductive, inductive, implicit and incidental grammatical instruction in second language classrooms". System, 45: 198-210. doi:10.1016/j.system.2014.06.003

Ur, P. 2011. "Grammar teaching: Research, theory, and practice." In Handbook of Research in Second Language Teaching and Learning, Volume II, edited by E. Hinkel, 507-522. New York: Routledge.

Van Patten, B. 1996. Input Processing and Grammar Instruction in Second Language Acquisition: Theory and Research. Norwood, NJ: Ablex Publishing Corporation.

Van Patten, B. 2002. "Processing instruction: An update." Language Learning 52 (4): 755803. doi:10.1111/1467-9922.00203

Van Patten, B., and O. Uludag. 2011. “Transfer of training and processing instruction: From input to output." System 39: 44-53. doi: 10.1016/j.system.2011.01.013

Vold, E. T. 2017. “Qualifying foreign language teachers: Is teacher training enough?” International Journal of Educational Research 82: 40-53. doi:10.1016/j.ijer.2016.12.002

\section{Analyzed textbooks:}

Jorand, V.D. 2006. C'est Chouette 1. Textes et exercises. Oslo : Gyldendal

Lokøy, G., and B. Ankerheim. 2009. Countours nouvelle édition. Oslo : Gyldendal

Hønsi, H., C. Kjetland, and S. Liautaud. 2012. Enchanté 1. Oslo : CappelenDamm Undervisning.

Christensen, H., and T. Wulff. 2006. Ouverture 8. Bergen : Fagbokforlaget. 